\section{Reaching Out to}

\section{Parents}

Tess Prendergast, Betsy Diamant-Cohen, and Annette Y. Goldsmith

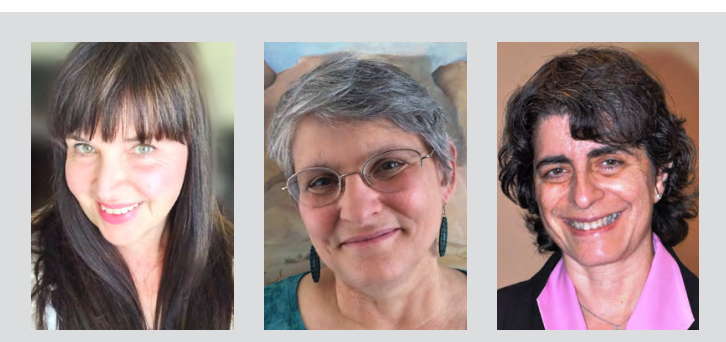

Tess Prendergast, PhD, is a Canadian children's librarian, researcher, and educator. Her most recent scholarly research explores early literacy in the lives of children with disabilities with a focus on the role of children's librarians. She works as a children's librarian in Vancouver, British Columbia, and teaches youth services courses at two post-secondary library education programs. Betsy Diamant-Cohen, DHD, is an early literacy trainer and Executive Director of Mother Goose on the Loose, Baltimore. Annette Y. Goldsmith, PhD, is a synagogue librarian at the Sephardic Temple Tifereth Israel in Los Angeles.
$\mathrm{M}$ ost parents will agree that parenting, while rewarding, is also a very difficult job. When we provide for families in our library spaces, we really need to "be there" for parents so they feel welcome bringing their children to the library. Smiling at everyone, adults and children, when they enter the children's room, can go a long way towards making them feel comfortable.

Also, parents are very sensitive to what they perceive as surveillance and judgment from other parents as well as library staff. A withering look or brisk admonishment from a staff person is all it takes for a frazzled parent to decide they are not welcome and they likely won't be back. We need to ensure that we give parents consistently welcoming messages and encouragement, especially when we are addressing specific issues or problems with them. This column's links are meant to help all children's library staff members to develop in our roles as supportive resource people in all parents' lives as they raise their children.

\section{Ideabook: Libraries for Families}

https://www.packard.org/insights/resource/ideabook-libraries-families/ From a partnership between the Public Library Association and the Harvard Family Research Project, Ideabook offers a research-based framework to guide libraries' work in family engagement. Well-organized, easy-to-read, practical and flexible, this free, downloadable guidebook is a must for those who are looking to bolster and reinvigorate the way they are connecting with and supporting families. The five foundational practices of effective family engagement (Reach out; Raise up; Reinforce; Relate; and Reimagine) are defined and fully explained with case examples.

\section{Zero to Three}

https://www.zerotothree.org/parenting

This site for parents with babies from birth to age three focuses on transforming the science of early childhood into helpful resources, practical tools, and responsive policies for millions of parents. It contains practical information for early childhood and health professionals who work with young children and their caregivers as well as directly for parents. Short video clips supplement handouts and clearly written information on a variety of topics such as potty training, early literacy, developing self-esteem in the early years, and preparing for parenthood. This site supports ECRR's claim that parents are a child's first and best teacher and maintains that there is no "one-size-fits-all" approach to raising children.

\section{Early Learning with Families 2.0}

http://elf2.library.ca.gov/

Early Learning with Families (ELF) is a Californian initiative that aims to support the ongoing evolution of library services to young children $(0-5)$, their families and caregivers. This straightforward website contains small segments of information that can be used by anyone in any library to help rationalize a family-centered approach to developing impactful library services, programs, and collections for families with young children. Their approach to parents is based on Brazelton Touchpoints Center 
(https://www.brazeltontouchpoints.org/) and emphasizes, among other things, that all parents are experts on their own children, bring their strengths, and have critical things to share during each of their child's developmental stages.

Working with Teen Parents at Your Library: Where to Begin https:// www.alsc.ala.org/blog/2018/08/working-with-teen -parents-at-your-library-where-to-begin/

Kathryn Woody's blog post on behalf of the ALSC Library Service to Underserved Children and Their Caregivers committee outlines how to locate community partners, define your goals, and design your program for teen parents. A libguide covers general resources, including a handy list of nonfiction titles designed to help these teens develop their parenting skills. For inspiration, check out the links to four quite different but successful library programs, all of which have in common a respectful approach to teen parents as library users. Programs often include donated or purchased giveaways (books, car seats, etc.) along with the requisite training in early literacy.

\section{The Right Stuff listserv}

http://fpg.unc.edu/presentations/right-stuff

Compiled by Camille Catlett, this is a free monthly one-way listserv supported by the Vermont Agency of Education. Funded by the Vermont Race to the Top Early Learning Challenge Grant, each issue features resources for supporting the learning and development of young children who are culturally, linguistically, and individually diverse, birth to Grade 3, and their families. Past issues can be accessed at the website above; all issues may be freely shared or reproduced.

\section{Scary Mommy Blog}

https://www.scarymommy.com/

The Scary Mommy blog was started in 2008 by mom Jill Smokler as an online baby book to chronicle her stay-at-home days with her children. Other moms who were feeling challenged, lonely, frustrated, and clueless latched onto her perky words conveying the theme that parenting doesn't have to be perfect. Although the site is now run by the Some Spider media company, the cheerful irreverent tone accompanying the practical advice and everyday life stories has attracted millions of parents. This is a great site to recommend to parents who seem to be overwhelmed and want to hear what other mothers have to say.

\section{Read-a-Rama}

https://read-a-rama.org/

Developed by Dr. Michelle Martin, Read-a-Rama is an actionpacked literacy program for children ages 4-11 and their families, especially underserved families, that uses children's books as the springboard for all the activities. In addition to running forty-hour week-long summer camps, Read-a-Rama also partners with churches, libraries, community centers, and homeless shelters for year-round programming. Read-aRama combines books, music, art, physical activity, and more to get families excited about reading.

¡Colorín Colorado! Parent Guide: The Resources at Your Library http://www.colorincolorado.org/guide/parent-guide -resources-your-library

Research-based bilingual education site Colorín Colorado is well known to children's librarians, but as with any large site, there are often hidden gems. This handout for parents (also available in Spanish) is an excellent outreach tool for families new to library services. You will also find a four-minute video, "Reaching out to Latino families," featuring author and literacy advocate Pat Mora, which emphasizes developing a relationship of trust to dispel families' feelings of fearfulness and vulnerability in coming to the library.

\section{Vroom}

https://www.vroom.org/

Vroom is a free subscription service of videos and developmental tips sent to a parent's phone daily. Each tip, available in English and Spanish, is based on brain science and targets the age of children. \& 